\title{
EFFICIENCY OF WATER USE IN SUNFLOWER GROWN IN HYDROPONIC SYSTEM UNDER SALINE STRESS ${ }^{1}$
}

\author{
JOSÉ AMILTON SANTOS JÚNIOR ${ }^{2}$, HANS R. GHEYI ${ }^{3}$, \\ DOROTEU H. G. FILHO ${ }^{4}$, FREDERICO A. L. SOARES ${ }^{5}$, NILDO DA S. DIAS ${ }^{6}$
}

\begin{abstract}
In order to identify alternatives for the use of saline water in agricultural production, the effects of the use of brackish water in the preparation of the nutrient solution for the cultivation of sunflower (cv. EMBRAPA 122-V2000) were studied in hydroponic system on consumption and efficiency of water use for the production of achenes and biomass. A completely randomized design was used, analyzed in a 5x2 factorial scheme with three replications. The factors studied were five levels of salinity of nutrient solution (1.7 - control; 4.3; $6.0 ; 9.0$; and $\left.11.5 \mathrm{dS} \mathrm{m}^{-1}\right)$ and two plant densities - one or two plants per vessel. It was concluded that the water consumption of sunflower is a variable sensitive to the salinity of the nutrient solution, especially after the fourth week of crop, and that the efficiency of water use in the production of achenes and biomass of sunflower is greater when the plant density increases from one to two plants per vessel, even under saline stress.
\end{abstract}

KEYWORDS: salinity, plant density, soilless culture, Helianthus annuus L..

\section{EFICIÊNCIA DO USO DA ÁGUA PARA GIRASSOL CULTIVADO EM SISTEMA HIDROPÔNICO SOB ESTRESSE SALINO}

RESUMO: Na busca por alternativas para a utilização de águas salinas na produção agrícola, estudaram-se os efeitos do uso da água salobra no preparo da solução nutritiva para o cultivo do girassol (cv. EMBRAPA 122-V2000), em sistema hidropônico, sobre o consumo e a eficiência de uso da água para a produção de aquênios e fitomassa. Utilizou-se um delineamento experimental inteiramente casualizado, analisado em esquema fatorial $5 \times 2$, com três repetições, sendo estudados

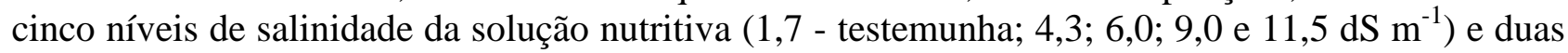
densidades de plantas - uma ou duas plantas por vaso. Concluiu-se que o consumo hídrico do girassol é uma variável sensível à salinidade da solução nutritiva, principalmente a partir da quarta semana de cultivo, e que a eficiência do uso da água na produção de aquênios e fitomassa pelo girassol é maior quando a densidade de plantio aumenta de uma para duas plantas por vaso, inclusive sob estresse salino.

PALAVRAS-CHAVE: salinidade, densidade de plantio, cultivo sem solo, Helianthus annuus L..

\section{INTRODUCTION}

The sunflower (Helianthus annuus L.) originated in North America, but is cultivated on every continent, due to its wide adaptability to different environmental conditions, and its productivity is slightly influenced by latitude, altitude and photoperiod (SOUZA et al., 2010); its use is extremely significant because it is a crop which takes advantage of all parts with high commercial value (NOBRE et al., 2008) due to its peculiar characteristics of hardiness, drought resistance, beauty,

\footnotetext{
${ }^{1}$ Trabalho extraído de parte da Dissertação de Mestrado do primeiro autor.

${ }^{2}$ Eng $^{\circ}$ Agrícola, Doutor em Engenharia Agrícola, Instituto Nacional do Semiárido - INSA/MCT. Av Francisco Lopes de Almeida,

S/N, Bairro Serrotão, CEP: 58.429-970, Campina Grande, PB; eng.amiltonjr@hotmail.com.

${ }^{3}$ Eng $^{\circ}$ Agrônomo, Professor Visitante Nacional Sênior, Núcleo de Engenharia de Água e Solo da Universidade Federal do

Recôncavo da Bahia, UFRB, Cruz das Almas, BA; hans@agriambi.com.br.

${ }^{4}$ Eng $^{\circ}$ Agrônomo, Doutorando em Engenharia Agrícola - DEAg/UFCG, Campina Grande, PB; doroteufilho@hotmail.com.

${ }^{5}$ Eng $^{\circ}$ Agrônomo, Professor Adjunto, Instituto Federal de Educação, Ciência e Tecnologia Goiano, Rio Verde-GO; fredalsoares@hotmail.com.

${ }^{6}$ Eng $^{\circ}$ Agrônomo, Dr. Bolsista do CNPq, Professor do Departamento de Ciências Ambientais e Tecnológicas da UFERSA. BR 110 Km 47. Costa e silva. CEP 59625-900. Mossoró, RN; nildo@ufersa.edu..br.

Recebido pelo Conselho Editorial em: 11-8-2011
}

Aprovado pelo Conselho Editorial em: 27-2-2013 
content and quality of oil. It covers areas such as floriculture (NEVES et al., 2007), food (RACT \& GIOIELLI, 2008), bioenergy (FERRARI \& SOUZA, 2009) and forage crops, and can be used in the production of silage (FREITAS et al., 2010). Its cultivation favors the colonization of the root region by mycorrhizal fungi and acts in recycling nutrients, favoring the succeeding crops (BARROSO et al., 2009).

As the cultivation of sunflower gains importance in Brazil, it is necessary to develop technologies in order to optimize its supply chain and increase productivity, performance and profitability, according to what each region of the country can offer. In northeastern Brazil, specifically, whose area is embedded largely in semi-arid zones, one of the barriers to the productive chain of sunflower is the irregularity of rainfall and lack of good quality surface water resources that could be used for irrigation, as the waters of subsurface reserves have a high salt content (DIAS et al., 2011).

Considering the quality of available water resources in semiarid regions, it is necessary to seek alternatives that enable the use of available brackish water in the sunflower production process efficiently. LEAL et al. (2008) claimed that various practices may be used to produce satisfactorily in water conditions with high risk of salinization, among which stands out the use of plants tolerant to salinity and sodicity associated with the choice of an irrigation system appropriate for the situation of cultivation.

Another important aspect when we relate the scarcity of water resources in agricultural production is the efficiency of water use by plants. Several authors have evaluated the efficiency of water use for a variety of crops under different water, soil and plant managements (BUTTAR et al., 2007; DETAR, 2008; EHOLPANKULOV et al., 2008; PEREIRA et al., 2009), indicating the importance of this study, especially in arid and semiarid regions. However, studies that seek to propose mechanisms to improve the efficiency of water use under saline stress are scarce.

One alternative to equate such factors would be the use of hydroponic cultivation systems; as soil is not used as a means to support the plants, the matric potential in hydroponic systems tends to be zero, affecting water absorption by plants only by osmotic potential of the nutrient solution. Another advantage of this cultivation system is the recycling of nutrients, which may minimize costs as well as mitigate environmental contamination coming from the leaching of fertigation (ALBORNOZ et al., 2,007), and therefore provide considerable savings of water and fertilizers, reconciled with high yields, i.e., optimizing consumption and efficiency of water use in agricultural production systems.

Supported by the arguments above, this study aimed to analyze water consumption to optimize the efficiency of its use in the production of sunflower achenes and biomass grown hydroponically under saline stress.

\section{MATERIAL AND METHODS}

The experimental activities were conducted from September to December, 2009, in a protected environment, like a greenhouse, located in the Campus I of the Federal University of Campina Grande, Campina Grande city, in the state of Paraíba (PB), in Brazil, (7¹2’52” South latitude, 3554'24” West longitude, and mean altitude of $550 \mathrm{~m}$ ).

The experimental design was completely randomized, analyzed in a $5 \times 2$ factorial scheme with three replications, so that we were able to study five levels of salinity of the nutrient solution (1.7 control; 4.3; 6.0; 9.0; and 11.5dS $\mathrm{m}^{-1}$ ) and two planting densities: one plant (D1) and two plants (D2) per vessel.

Each experimental plot consisted of a vessel with a volume capacity equivalent to $6 \mathrm{~L}$, which were filled with $0.5 \mathrm{~kg}$ of gravel at the bottom, a nylon screen as an envelope separating the gravel and substrate, and, finally, $1.2 \mathrm{~kg}$ of substrate (coconut fiber). The vessels were prepared with four holes at the base and put in a bowl where a drain hose was adapted and connected to a 2L plastic 
bottle to collect the drained solution; given the direct contact at the interface between the vessel and the bowl, the solution runoff was given through the existent micro-spaces, favoring the retention of the solution within the vessel for a longer time, providing a greater absorption time for the plant at each irrigation event, until all the solution was drained. This prevented that, under the action of gravity, the solution was drained through preferred paths, without wetting all the substrate, preventing the redistribution of the nutrient solution, compromising the nutritional and water requirements of the plants.

The nutrient solution used was proposed by FURLANI et al. (1999), and its chemical composition is shown in Table 1, with the electrical conductivity (EC) of the original solution of $3.4 \mathrm{dS} \mathrm{m} \mathrm{m}^{-1}$. This solution was diluted equally in supply water (Table 2), resulting in an electrical conductivity of the nutrient solution of $1.7 \mathrm{dS} \mathrm{m} \mathrm{m}^{-1}$ (control). In order to obtain the saline treatments, increasing amounts of $\mathrm{NaCl}$ were added to the solution diluted according to the following equation (RICHARDS, 1954): $\mathrm{mg} \mathrm{L}^{-1}(\mathrm{NaCl})=640$. (desired EC - current EC).

TABLE 1. Composition of nutrient solution used in study.

\begin{tabular}{lc}
\hline Salt or fertilizer & $\mathrm{g} .1000 \mathrm{~L}^{-1}$ \\
\hline Calcium nitrate hydro special & 750.0 \\
Potassium nitrate & 500.0 \\
Monoammonium phosphate (MAP) & 150.0 \\
Magnesium sulfate & 400.0 \\
Copper sulfate & 0.15 \\
Zinc sulfate & 50.0 \\
Manganese sulfate & 1.50 \\
Boric acid & 1.50 \\
Sodium molybdate $\left(\mathrm{Na}_{2} \mathrm{MoO}_{4} \cdot 2 \mathrm{H}_{2} \mathrm{O}\right)$, & 0.15 \\
Ammonium molybdate & 0.15 \\
Fe EDDHMA-6\% Fe & 30.0 \\
\hline
\end{tabular}

Source: FURLANI et al. (1999)

TABLE 2. Characteristics of the supply water used in the preparation of the standard nutrient solution.

\begin{tabular}{ccccccc}
\hline $\mathrm{pH}$ & $\mathrm{EC}_{\mathrm{a}}$ & $\mathrm{K}$ & $\mathrm{Na}$ & $\mathrm{Ca}$ & $\mathrm{Mg}$ & \\
\cline { 3 - 6 } & $\mathrm{dS} \mathrm{m}^{-1}$ & & & $\mathrm{mg} \mathrm{L}^{-1}$ & & $\begin{array}{c}\mathrm{RAS} \\
\left(\mathrm{mmol} \mathrm{L}^{-1}\right)^{0.5}\end{array}$ \\
\hline 7.5 & 0.38 & 5.47 & 35.65 & 20.00 & 15.8 & 1.45 \\
\hline
\end{tabular}

In the management of irrigation, an initial volume of $2 \mathrm{~L}$ of nutrient solution was applied per vessel with daily recirculation of the leached nutrient solution at 8,12 and 16 hours, i.e., at 8 o'clock the volume of the solution drained into collectors was measured, annotated, and then applied to the vessels; at 12 and at 16 o'clock, the drained solution was only reapplied. When the drained volume reached the limit of $200 \mathrm{~mL}$, it was discarded and a new nutrient solution as treatment was prepared.

The variables studied were assessed during daily mensurations of water consumption and harvesting; the water consumption (WC) was daily monitored until the plants reached the stage of physiological maturity $\left(\mathrm{R}_{9}\right)$, according to criteria proposed by SCHNEITER \& MILLER (1981), being expressed as mean weekly water consumption $\left(\mathrm{S}_{1}, \mathrm{~S}_{2}, \mathrm{~S}_{3}, \mathrm{~S}_{4}, \mathrm{~S}_{5}, \mathrm{~S}_{6}, \mathrm{~S}_{7}, \mathrm{~S}_{8}, \mathrm{~S}_{9}, \mathrm{~S}_{10}\right.$ and $\left.\mathrm{S}_{11}\right)$ and at harvest, the efficiency of water use for the production of achene (EA) and biomass (EB) of sunflower were determined.

The results of the experiment were subjected to analysis of variance, comparing by means of regression analysis the salinity levels of the nutrient solution (quantitative factor) and through mean test (Tukey) the planting densities (qualitative factor) at a 0.05 level of probability. Seeking a better 
homogeneity of the data, we used the transformation $(X+1)^{0.5}$ for the variables of efficiency of water use for the production of achenes and biomass. We conducted all analysis using the statistical program SISVAR 5.2 (FERREIRA, 2008).

\section{RESULTS AND DISCUSSION}

Regarding water consumption (WC) of the plants, we verified that the salinity factor of the nutrient solution $\left(E C_{n s}\right)$ provided significant effect $(\mathrm{p}<0.01)$ in all evaluated weeks, except in $\mathrm{S}_{1}$. As for the cultivation density factor, there were significant results $(p<0.05)$ from $S_{3}$ to $S_{8}$; in addition, the interaction between the factors tested was statistically significant $(<0.01)$ in $\mathrm{S}_{4}$ and $\mathrm{S}_{8}$ (Table 3).

TABLE 3. Summary of ANOVA for the weekly (S) water consumption of sunflower (cv. EMBRAPA 122-V2000) grown in hydroponic system under saline stress and two plant densities, at different stages of evaluation.

\begin{tabular}{|c|c|c|c|c|c|c|c|c|c|c|c|c|}
\hline \multirow{2}{*}{ Variation Source } & \multirow{2}{*}{ GL } & \multicolumn{11}{|c|}{ "F" Test } \\
\hline & & $\mathrm{S}_{1}$ & $\mathrm{~S}_{2}$ & $\mathrm{~S}_{3}$ & $\mathrm{~S}_{4}$ & $\mathrm{~S}_{5}$ & $\mathrm{~S}_{6}$ & $\mathrm{~S}_{7}$ & $\mathrm{~S}_{8}$ & $\mathrm{~S}_{9}$ & $\mathrm{~S}_{10}$ & $\mathrm{~S}_{11}$ \\
\hline Salinity Level - N & 4 & ns & $* *$ & $* *$ & $* *$ & $* *$ & $* *$ & ** & $* *$ & $* *$ & $* *$ & $* *$ \\
\hline Linear Regression & 1 & ns & $* *$ & $* *$ & $* *$ & $* *$ & $* *$ & $* *$ & $* *$ & $* *$ & $* *$ & $* *$ \\
\hline Quadratic Regression & 1 & ns & $*$ & $* *$ & $* *$ & ns & ns & $* *$ & $* *$ & ns & $* *$ & ns \\
\hline Reg Deviation & 2 & ns & ns & ns & ns & ns & ns & $* *$ & ns & ns & ns & ns \\
\hline Density - D & 1 & ns & ns & $*$ & $* *$ & $*$ & $*$ & ns & $* *$ & ns & ns & ns \\
\hline $\mathrm{N} \times \mathrm{D}$ & 4 & ns & ns & ns & $* *$ & ns & ns & ns & $* *$ & ns & ns & ns \\
\hline Residue & 18 & 315 & 2578 & 1828 & 6213 & 3042 & 1548 & 2189 & 1319 & 1706 & 1421 & 1168 \\
\hline CV (\%) & & 12 & 11 & 8 & 13 & 25 & 20 & 20 & 15 & 50 & 44 & 35 \\
\hline
\end{tabular}

${ }^{*}$ and ${ }^{* *}=$ significative at 0.05 and 0.01 probability by $\mathrm{F}$ test, respectively; ${ }^{\mathrm{ns}}=$ not significant at 0.05 probability.

It was observed that the water consumption presented quadratic behavior to increasing salinity levels in the second week of evaluation $\left(\mathrm{S}_{2}\right)$, and we estimated, based on the regression equation (Figure 1A), that the mean water consumption of plants irrigated with nutrient solution of $4.3 \mathrm{dS} \mathrm{m} \mathrm{m}^{-1}$ decreases in the order of $10.7 \%$ in relation to plants growing in the nutrient solution of electrical conductivity (ECns) of $1.7 \mathrm{dS} \mathrm{m} \mathrm{m}^{-1}$ (control). Further reductions in water consumption were observed in plants irrigated with high EC; for example, for $\mathrm{EC}_{\mathrm{ns}}$ of 6,9 and $11.5 \mathrm{dS} \mathrm{m} \mathrm{m}^{-1}$, there were reductions of $14.97,17.27$, and $14.08 \%$, respectively, in water consumption of the plants when compared to the $\mathrm{EC}_{\mathrm{ns}}$ of the control treatment. Considering that the water absorption by the plant is a passive process, which depends on the water potential gradient $(\Delta \Psi \mathrm{w})$ and the resistances in the path, it was possible to infer that the different $\mathrm{EC}_{\mathrm{ns}}$ tested reduced the free energy of water and, consequently, the water potential gradient by diluting it, causing a reduction in water consumption by plants. Another force acting on the water absorption is transpiration, which depends on a favorable water potential gradient and the size of the evaporating surface; as different levels of $\mathrm{EC}_{\mathrm{ns}}$ tested caused a reduction in stomatal aperture and also in leaf area, water consumption was directly affected. Another aspect to be considered is the flow resistance in the roots, which is directly influenced by the reduction in hydraulic conductivity in this organ, also caused by $\mathrm{EC}_{\mathrm{ns}}$ (LEONARDO et al., 2007; TAIZ \& ZEIGER, 2004).

The results estimated from the regression equation for water consumption in $\mathrm{S}_{3}$ (Figure 1A) indicate that increased $\mathrm{EC}_{\mathrm{ns}}$ provides the quadratic decrease of water consumption by plants; we estimated that consumption was about 11.4, 16.78, 22.5 and 22.9\% lower for plants irrigated with $\mathrm{EC}_{\mathrm{ns}}$ of 4.3, 6, 9 and $11.5 \mathrm{dS} \mathrm{m}^{-1}$, respectively, when compared with control. Still in this evaluation period, there was a significant effect $(\mathrm{p}<0.05)$ of the density of cultivation factor, in which we note mean consumption in $S_{3}$ of $1,559 \mathrm{~mL}$ in the density of one plant per vessel, and 1,693 $\mathrm{mL}$ for the density of two plants per vessel, i.e., with two plants, the water consumption had an mean increase of only $7.91 \%$. 
In $\mathrm{S}_{4}$, the effect of $\mathrm{EC}_{\mathrm{ns}}$ increase caused quadratic reduction in water consumption. It was estimated, based on the regression equation (Figure 1A), a decrease of 17.85, 25.85, 32.92 and $31.92 \%$ in water consumption of plants irrigated with $\mathrm{EC}_{\mathrm{ns}}$ of $4.3,6,9$ and $11.5 \mathrm{dS} \mathrm{m} \mathrm{m}^{-1}$, respectively, related to control. As for the density factor of plants per vessel, at this period of evaluation, the difference between the water consumption in the vessel with one and two plants was $17.8 \%$, in which we observed mean consumption of 1,742 and 2,119mL, respectively (Figure 2).

The interaction between the tested factors also influenced the water consumption by plants in $\mathrm{S}_{4}$. Based on the deployment, it is clear that, in this period of evaluation, there was significance for the salinity factor of the nutrient solution within $\mathrm{D}_{2}$, so that we noticed a linear decrease in water consumption by plants per unit increase of $\mathrm{EC}_{\mathrm{ns}}$, calculated based on regression equation (Figure $3 \mathrm{~A}$ ), in the order of $4.65 \%$. It was also observed in $\mathrm{S}_{4}$ the significance of planting density factor in the nutrient solution salinity factor at levels 1.7 and $4.3 \mathrm{dS} \mathrm{m}^{-1}$. When irrigated with $\mathrm{EC}_{\mathrm{ns}}$ of $1.7 \mathrm{dS}$ $\mathrm{m}^{-1}$, we observed in vessels containing two plants an mean water consumption of $2,960 \mathrm{~mL}$, and in vessels containing one plant, a consumption of $1,980 \mathrm{~mL}$, i.e., a mean difference of $49.49 \%$. On the other hand, when irrigated with $\mathrm{EC}_{\mathrm{ns}}$ of $4.3 \mathrm{dSm}^{-1}$, we observed consumption means of 1,803 and $2,310 \mathrm{~mL}$, i.e., in vessels with two plants the water consumption was only $28.12 \%$ higher when compared with the vessels cultivated with one plant (Figure 3B).

The decrease in water consumption due to the increase in salinity of the nutrient solution in $\mathrm{S}_{5}$ and $S_{6}$ showed linear behavior; it was estimated, based on the regression equation (Figure 1B), a reduction by unit increase in salinity in the order of $3.7 \%$ for $S_{5}$ and $4 \%$ for $S_{6}$. Since there is no comparable data in the literature for the sunflower crop, we will compare the effect of salinity on water consumption in other oilseeds crops; SOUZA et al. (2011), when studying the water consumption of jatropha under saline stress during 180 days after transplanting, observed that water consumption with increasing salinity of irrigation water was reduced by $22.5 \%$ per unit increase in the electrical conductivity of water between 0.6 and 3.0dS m${ }^{-1}$; NERY et al. (2009), studying five levels of salinity of irrigation water on jatropha plants in the second year of cultivation, found in evaluations every 21 days that there was a reduction of $59.45 \%$ in water consumption when the electrical conductivity of water increased from 0.6 to $3.9 \mathrm{dS} \mathrm{m}^{-1}$.

The density factor of plants per vessel also influenced water consumption at this period of the cycle (Figure 2); we observed in $\mathrm{S}_{5}$ a mean consumption of 1,998 and 2,441mL (difference of $18.15 \%$ ), and in $S_{6}$ means of 1,780 and $2,229 \mathrm{~mL}$ (difference of $20.14 \%$ ), for vessels with one and two plants, respectively.

The water consumption of the plants in the $S_{7}$ presented quadratic behavior. Based on the regression equation (Figure 1B), we estimated decreases of approximately 24.36, 35.65, 46.64 and $47.1 \%$ in plants irrigated with $\mathrm{EC}_{\mathrm{ns}}$ of $4.3,6,9$ and $11.5 \mathrm{dS} \mathrm{m}^{-1}$, respectively, when compared with the plants irrigated with $\mathrm{EC}_{\mathrm{ns}}$ of $1.7 \mathrm{dS} \mathrm{\textrm {m } ^ { - 1 }}$. Similar results were observed by SILVA et al. (2008) who, observing the values of water consumption of castor bean (cultivar BRS Paraguaçu and BRS Energia) under saline stress at 100 days after sowing, noted that there was a quadratic decrease in water consumption by plants; they found a reduction of up to 93.2 and $87.8 \%$ for cultivars BRS Paraguaçu and BRS Energia, respectively, and concluded that the general trend was of a reduction of water consumption, at the highest salinity levels, with the advancement of cycle.

In $\mathrm{S}_{8}$, the water consumption by plants was reduced quadraticaly with the increase of salinity in the nutritive solution; we estimated, based on the regression equation (Figure 1C), mean reductions of the order of 30,44, 55.5 and $58.87 \%$ in water consumption of plants irrigated with $\mathrm{EC}_{\mathrm{ns}}$ of 4.3, 6, 9 and $11.5 \mathrm{dS} \mathrm{m} \mathrm{m}^{-1}$, respectively, when compared to plants irrigated with $\mathrm{EC}_{\mathrm{ns}}$ of $1.7 \mathrm{dS}$ $\mathrm{m}^{-1}$. The density of plants per vessel also influenced significantly $(\mathrm{p}<0.05)$ the water consumption at this period of the cycle of sunflower; we observed means of 2,097 and 2,621mL, i.e., a difference of $20 \%$ in water consumption in vessels with one and two plants, respectively (Figure 2). We also observed significant results for the interaction between the factors tested at this period of the crop cycle $\left(\mathrm{S}_{8}\right)$; as a result of the statistic deployment (Figure 3), it appears that there was a significant 
effect for the salinity factor of the nutrient solution within the $\mathrm{D}_{2}$ (Figure $3 \mathrm{C}$ ), so that, based on the regression equation, linear mean reductions of water consumption of plants per unit increase of $\mathrm{EC}_{\mathrm{ns}}$ of the order of $7.31 \%$ were estimated. We also observed significance for the planting density factor inside salinity factor of the nutritive solution (Figure 3C), where we noted an mean water consumption of the plants in the order of 2,856 and 4,683mL (difference of 39\%) at the vessels with one and two plants, respectively, and irrigated with $\mathrm{EC}_{\mathrm{ns}}$ of $1.7 \mathrm{dS} \mathrm{\textrm {m } ^ { - 1 }}$.

In $\mathrm{S}_{9}$ the water consumption decreased linearly with increasing salinity of the nutrient solution. It was estimated, based on the regression equation (Figure 1C), a decrease of 6.57\% per unit increase of $\mathrm{EC}_{\mathrm{ns}}$, for this period of evaluation. CAVALCANTI (2003) found in castor bean (cultivar BRS-149 Nordestina) irrigated with saline water, with EC ranging between 0.7 and $4.7 \mathrm{dS}$ $\mathrm{m}^{-1}$ in the period of 80 DAS, a reduction in water consumption by up to $1.9 \mathrm{~L}$, with a $6.6 \%$ decrease per unit increase of the electrical conductivity of irrigation water.

We observed in $\mathrm{S}_{10}$, as well as in other evaluation periods, that there was a decrease in water consumption by plants with the increase of salinity of the nutrient solution. We estimated, based on the regression equation (Figure 1C), quadratic decreases in the order of 41, 58.1, 69.44 and 60.6\% in plants irrigated with $\mathrm{EC}_{\mathrm{ns}}$ of $4.3,6,9$ and $11.5 \mathrm{dS} \mathrm{m} \mathrm{m}^{-1}$, respectively, when compared with the plants irrigated with $\mathrm{EC}_{\mathrm{ns}}$ of $1.7 \mathrm{dS} \mathrm{m}^{-1}$. In $\mathrm{S}_{11}$ (Figure 1D) water consumption decreased linearly with the increase of salinity of the nutrient solution, and we estimated, based on the regression equation, a decrease of $4.67 \%$ per unit increase of $\mathrm{EC}_{\mathrm{ns}}$.

It is noteworthy that, as the cycle of the sunflower forwarded, the decrease in water consumption of the plants irrigated with saline increased, when compared with control, fact caused by reducing the surface area available for transpiration as well as by the effects in the hydraulic conductivity of the roots. This corroborates with the results observed by other researchers (DANTAS et al., 2010; DIAS et al., 2011 and SOUSA NETO et al., 2011), who stated that the effect of salinity on water availability and, consequently, the water consumption of plants vary, among other factors, with the phenological stage of the crop.
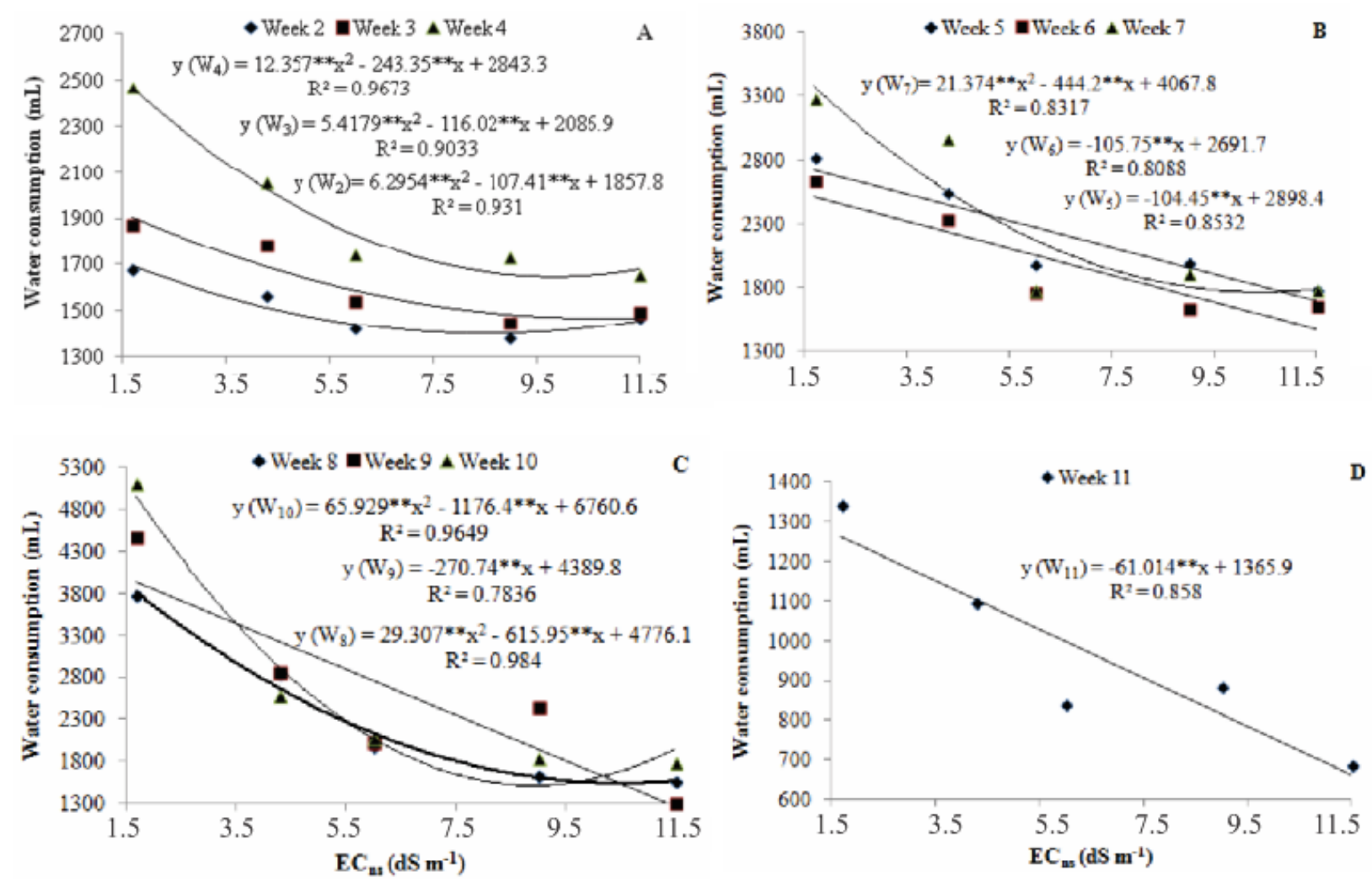

FIGURE 1. Mean water consumption of sunflower (cV. EMBRAPA 122-V2000), grown in hydroponic system with different planting densities, under saline stress, for different stages of evaluation. 


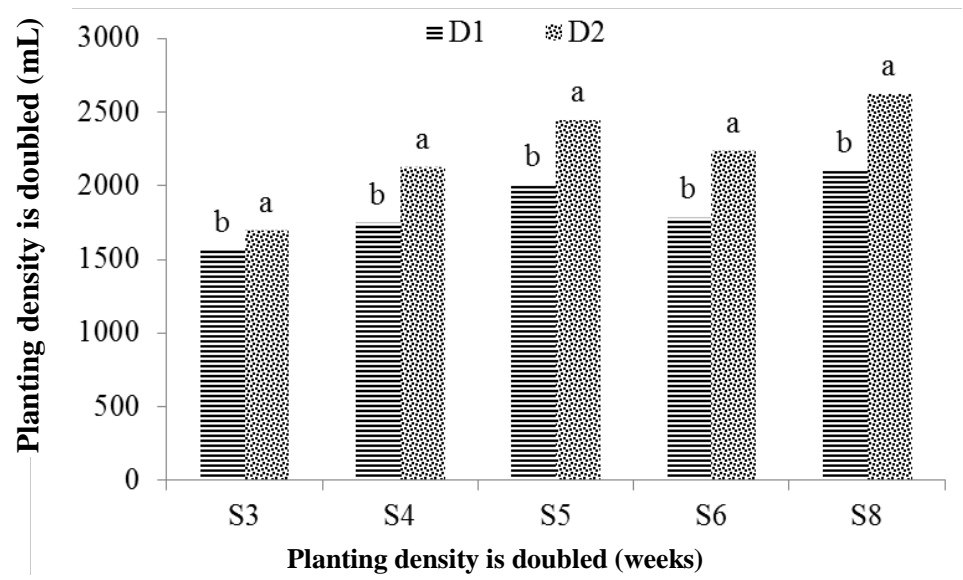

FIGURE 2. Histogram of the mean water consumption of sunflower (cv. EMBRAPA 122-V2000) grown in hydroponic system with different planting densities, under saline stress, for different stages of evaluation.
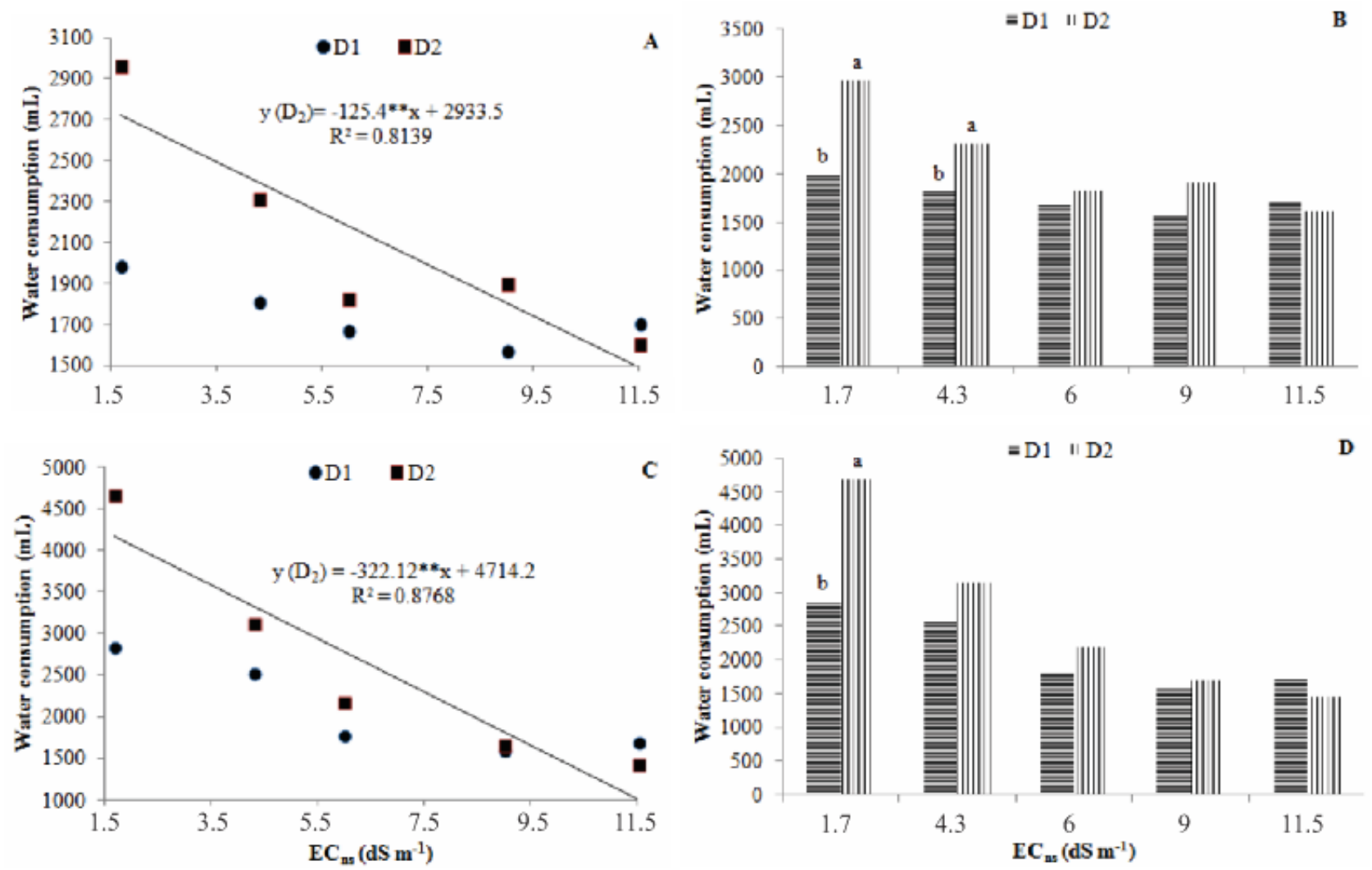

FIGURE 3. Deployment of salinity factor of the nutrient solution within the planting density factor during $\mathrm{S}_{4}(\mathrm{~A})$ and $\mathrm{S}_{8}(\mathrm{C})$; and planting density factor within the salinity of the nutrient solution during $\mathrm{S}_{4}(\mathrm{~B})$ and $\mathrm{S}_{8}(\mathrm{D})$ for the mean water consumption of sunflower (cv. EMBRAPA 122-V2000) grown in hydroponic system with different planting densities, under saline stress, for different stages of evaluation.

It is worth emphasizing the fact that the density, irrigation management and cultivation system used influenced the water consumption and, consequently, the efficiency of water use (Figure 4), and that the ratio water consumption-density does not happen in the same proportion, i.e., the water absorption is not duplicated at all saline levels tested, under equal conditions of availability of the nutritive solution, when planting density is doubled. 


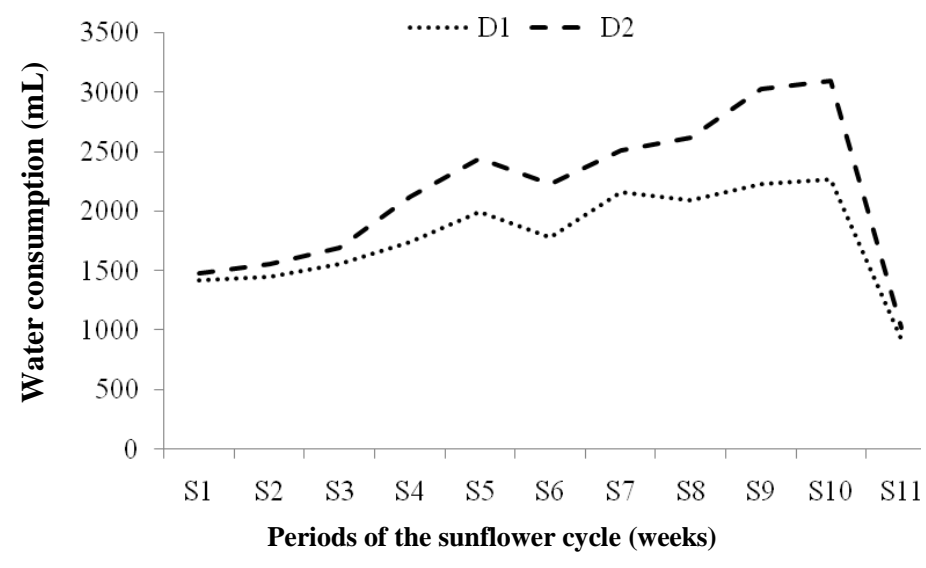

FIGURE 4. Mean weekly water consumption of sunflower plants (cv. EMBRAPA 122-V2000) grown in hydroponic system with different planting densities, under saline stress, for different stages of evaluation.

The efficiency of water use in the production of achenes (EA) and biomass (EB), i.e., the water volume $(\mathrm{mL})$ used by the plant to produce $1 \mathrm{~g}$ of achenes and biomass, was influenced significantly $(p<0.01)$ by salinity factor of the nutrient solution. The planting density factor influenced significantly $(\mathrm{p}<0.05)$ the $\mathrm{EB}$, and the interaction "salinity $\mathrm{x}$ density" influenced significantly $(\mathrm{p}<0.05)$ the EA (Table 4$)$.

TABLE 4. Summary of ANOVA for water use efficiency in the production of achenes (EA) and biomass (EB) by sunflower (cv. EMBRAPA 122-V2000) grown in hydroponic system with different planting densities, under saline stress.

\begin{tabular}{cccc}
\hline \multirow{2}{*}{ VARIATION CAUSE } & \multirow{2}{*}{ GL } & \multicolumn{2}{c}{ Mean square } \\
\cline { 3 - 4 } & & EA & EB \\
\hline Salinity Level - N & 4 & $0.000007^{* *}$ & $0.000011^{* *}$ \\
Linear Regression & 1 & $0.000027^{* *}$ & $0.000039^{* *}$ \\
Quadratic Regression & 1 & $0.000000^{\mathrm{ns}}$ & $0.000003^{\mathrm{ns}}$ \\
Reg Deviation & 2 & $0.000000^{\mathrm{ns}}$ & $0.000000^{\mathrm{ns}}$ \\
Density - D & 1 & $0.000002^{\mathrm{ns}}$ & $0.000014^{* *}$ \\
Interaction S x D & 4 & $0.000003^{*}$ & $0.000001^{\mathrm{ns}}$ \\
Residue & 18 & 0.00000928 & 0.000001 \\
CV & $(\%)$ & 0.10 & 0.11 \\
\hline
\end{tabular}

${ }^{*}$ and ${ }^{* *}=$ Significative at 5 and $1 \%$ probability by $\mathrm{F}$ test, respectively; ${ }^{\mathrm{ns}}=$ not significant at $5 \%$ probability.

Based on the regression equation (Figure $5 \mathrm{~A}$ and $5 \mathrm{~B}$ ), it is possible to observe that $\mathrm{EA}$ and $\mathrm{EB}$ decreased linearly with the unit increase of $\mathrm{EC}_{\mathrm{ns}}$ in the order of 10.17 and $7.3 \%$ respectively; this fact indicates the need for greater water consumption by the plant for the production of achenes and biomass as $\mathrm{EC}_{\mathrm{ns}}$ increases, and infers that the reduction in achenes and biomass production was more affected than the water consumption.

ACOSTA (2009) argued that, in a situation of growing in soil, sunflower has low efficiency in water use, and each liter of water consumed produces less than $2 \mathrm{~g}$ of dry matter. However, under conditions of water deficit, this efficiency increases by around 20-50\%. These results contrast with those observed in this work, since under an irrigation with $\mathrm{EC}_{\mathrm{ns}}$ of $1.7 \mathrm{dS} \mathrm{m} \mathrm{m}^{-1}$, we estimated, based on the regression equation, an efficiency of water use by sunflower in the order of 5.48 and $9.11 \mathrm{~g} \mathrm{~L}^{-}$ ${ }^{1}$ in the production of achenes and biomass, respectively, and, based on the regression equation (Figure 5A and 5B), reductions in water use efficiency by the sunflower were estimated under salinity stress by up to 80 and $56 \%$ when irrigated with $\mathrm{EC}_{\mathrm{ns}}$ of $9 \mathrm{dS} \mathrm{m}^{-1}$, in the production of achenes and biomass, respectively. 

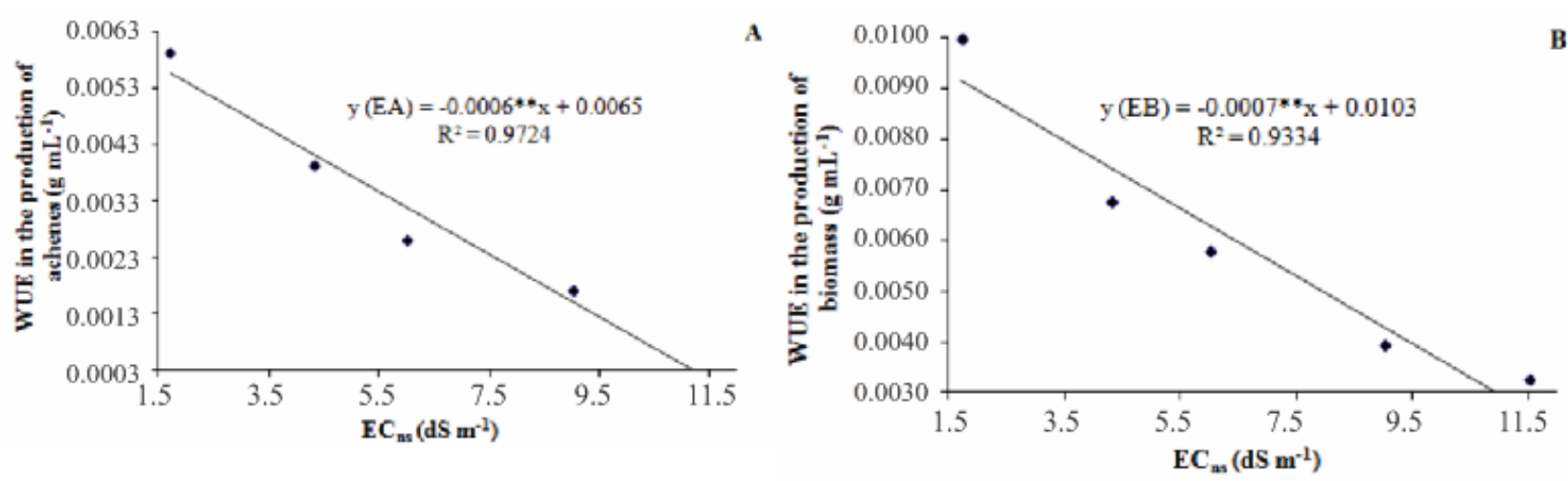

FIGURE 5. Water use efficiency (WUE) in the production of achenes (A) and biomass (B) of sunflower (cv. EMBRAPA 122-V2000) grown in hydroponic system with different planting densities, under saline stress.

Planting density influenced significantly $(\mathrm{p}<0.05)$ the EB. It was observed that, when using two plants per vessel, the volume of water used by plants to produce $1 \mathrm{~g}$ of biomass is lower; in this case, we observed a mean efficiency of 1.02 and $1.003 \mathrm{~g} \mathrm{~mL}^{-1}$ (1.67 \% lower), in vessels with one and two plants, respectively. SANTOS JÚNIOR et al. (2011), when studying the cultivation of sunflower in a hydroponic system, observed an increase of $51.9 \%$ in the production of fresh biomass of the shoot area with density of two plants per vessel, when comparing the values obtained in a vessel with one plant.

The deployment of the interaction between the factors tested for EA is presented in Figure 6. Note that the salinity factor of nutrient solution inside the plant density factor with two plants per vessel influenced the EA significantly $(\mathrm{p}<0.01)$, and it was estimated a linear decrease of the efficiency of water use per unit increase of $\mathrm{EC}_{\mathrm{ns}}$ of 10\% (Figure 6A). TRAVASSOS et al. (2011), when studying the production of sunflower achenes under saline stress, observed a linear decrease per unit increase in salinity of $12.8 \%$ in the production of achenes, using soil as substrate; SANTOS JÚNIOR et al. (2011), when studying the cultivation of sunflower in a hydroponic system under saline stress, recorded a decrease of $10.5 \%$ per $\mathrm{dS} \mathrm{m}^{-1}$ in the production of achenes, i.e., the reduction in water use efficiency affects directly the production of achenes.
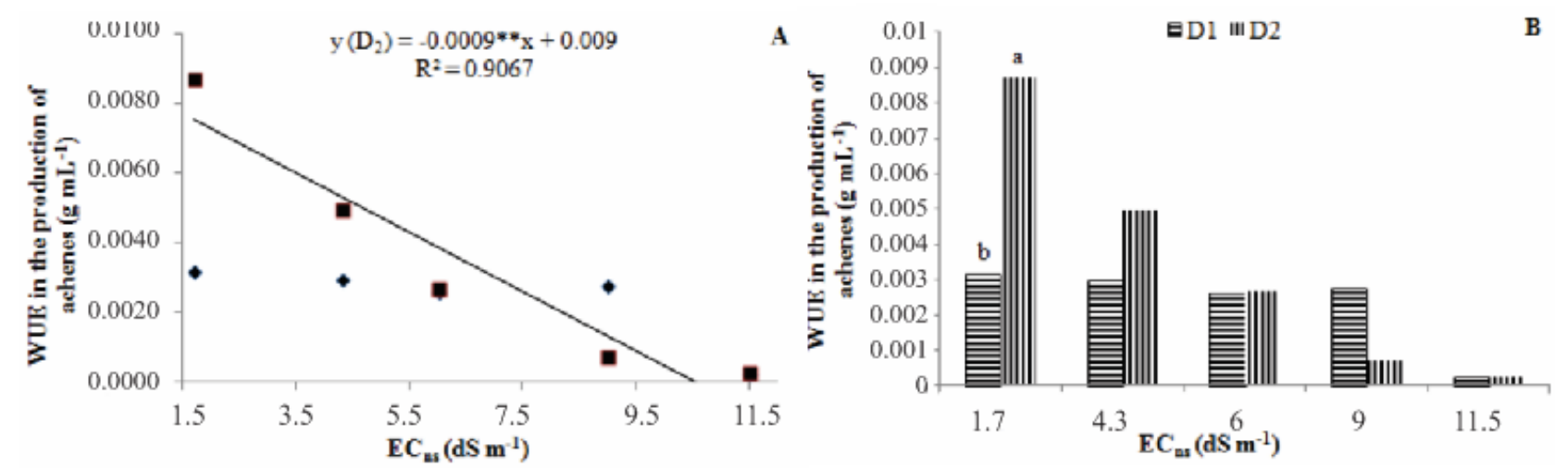

FIGURE 6. Deployment of salinity factor of the nutrient solution within the planting density factor (A) and the planting density factor within the salinity factor of the nutrient solution (B) regarding the efficiency of the production of achenes $\left(\mathrm{g} \mathrm{mL} \mathrm{L}^{-1}\right)$ of sunflower (cv. EMBRAPA 122-V2000) grown in hydroponic system with different planting densities, under saline stress.

The planting density factor within the salinity factor of the nutrient solution also influenced significantly $\left(\mathrm{p}^{<0.05}\right)$ the EA. In Figure $6 \mathrm{~B}$, it is observed that, in the plants irrigated with $\mathrm{EC}_{\mathrm{ns}}$ of $1.7 \mathrm{dS} \mathrm{m}^{-1}$, the mean water use efficiency by the sunflower in the production of achenes was 
0.003167 and $0.00871 \mathrm{~g} \mathrm{~mL}^{-1}$ (difference of 63.64\%), in the vessels with one and two plants, respectively, which demonstrates the advantages of using higher planting densities in a situation of saline stress. These results indicate that the planting density may be used as a strategy to mitigate the effect of salinity of irrigation water in the production of sunflower per unit of cultivated area. SILVA et al. (2009), when studying the performance of sunflower hybrids in reduced spacing, found that the increase of planting density provided a higher achene yield and number of seeds for each chapter.

\section{CONCLUSIONS}

1. The water consumption of sunflower plants is a variable which is sensitive to salinity of the nutrient solution, mainly from the 4th week of cultivation;

2. The water consumption does not increase in the same proportion of the density of plants per vessel, even under saline stress;

3. The density of plant per vessel may be used in order to minimize production losses caused by the effect of salinity of nutrient solution per unit of cultivated area;

4. The efficiency of water use in the production of sunflower achenes and biomass is greater with the increase of the planting density, even under saline stress.

\section{REFERENCES}

ACOSTA, J. F. Consumo hídrico da cultura do girassol irrigada na região da Chapada do Apodi$R N$. 2009. 56f. Dissertação (Mestrado) - Universidade Federal de Campina Grande, Campina Grande, 2009.

ALBORNOZ, F.; TORRES, A.; TAPIA, M. L.; ACEVEDO, E. Cultivo de tomate (Lycopersicon esculentum Mill.) hidropónico con agua desalinizada y desborificada en el valle de lluta. IDESIA, Chile, v. 25, n.2, p. 73-80, 2007.

BARROSO, G.R.P.; CARVALHO, J.O.M.; SANTOS, M.R.A. dos; FERREIRA, M. das G.R.; MARCOLAN, A.R. Teor de macronutrientes em plantas utilizadas como adubo verde. Revista Saber Científico, Porto Velho, v.2, n.1, p. 37 - 42, 2009.

BUTTAR, G. S; AUJLA, M. S.; THIND, H. S.; SINGH, C. J.; SAINI, K. S. Effect of timing of first and last irrigation on the yield and water use efficiency in cotton. Agricultural Water Management, Amsterdam, v.89, n.1, p.236-242, 2007.

CAVALCANTI, M. L. F. Germinação e crescimento inicial da mamoneira irrigada com águas salinas. Dissertação (Mestrado) - Campina Grande: UFCG, 2003, 46p.

DANTAS, D.C; SANTOS, R.S.S.; NOGUEIRA, F.P.; DIAS, N.S.; FERREIRA NETO, M. Utilização de águas salobras no cultivo hidropônico da alface. Irriga, Botucatu, v.15, p.111- 118, 2010.

DETAR, W. R. Yield and growth characteristics for cotton under various irrigation regimes on sandy soil. Agricultural Water Management, Amsterdam, v.95, n.1, p.69-76, 2008.

DIAS, N. S.; JALES, A. G. O.; SOUSA NETO, O.N.; GONZAGA, M.I.S.; QUEIROZ, I. S. R. Q.; PORTO, M. A. F. Uso de rejeito da dessalinização na solução nutritiva da alface cultivada em fibra de coco. Revista Ceres, Viçosa-MG, v.58, p.407-410, 2011.

DIAS, N. da S.; LIMA, F.A. de; SILVA, C.R. da; SOUSA NETO, O.N. de; GHEYI, H. R. Use of reject brine from desalination on different development stages of hydroponic lettuce. Revista Caatinga, Mossoró, RN, v. 24, n. 1, p. 76-81, 2011. 
EHOLPANKULOV, E. D.; INCHENKOVA, O. P.; PAREDES, P.; PEREIRA, L. S. Cotton irrigation scheduling in Central Asia: Model calibration and validation with consideration of groundwater contribution. Irrigation and Drainage, Slough, v.57, p.516-532, 2008.

FERRARI, R.A.; SOUZA, W.L. de; Avaliação da estabilidade oxidativa de biodiesel de óleo de girassol com antioxidantes, Revista Química Nova, São Paulo, v. 32 n.1, p. 106 - 111, 2009.

FERREIRA, D. F. Programa Sisvar versão 5.1. - programa de análises estatísticas. Lavras: DEX/UFLA, 2008.

FREITAS, L. da S.; SILVA, J.H.S. da; SEGABINAZZI, L.R.; SILVA, V.S. da; ALVES FILHO, D.C.; BRONDANI, I.L. Substituição da silagem de milho por silagem de girassol na dieta de novilhos em confinamento: comportamento ingestivo. Revista Brasileira de Zootecnia, Viçosa, MG, v. 39 n.1, p. 225 - 232, 2010.

FURLANI, P.R.; SILVEIRA, L.C.P.; BOLONHEZI, D.; FAQUIM, V. Cultivo hidropônico de plantas. Campinas: Instituto Agronômico, 1999. 52p.

LEAL, I.G.; ACCIOLY, A.M. de A.; NASCIMENTO, C.W.A. do; FREIRE, M.B.G. dos S.; MONTENEGRO, A.A. de A.; FERREIRA, F. de L. Fitorremediação de solo salino sódico por Atriplex nummularia e gesso de jazida. Revista Brasileira de Ciência do Solo, Viçosa, MG, v. 32, n.4, p.1065-1072, 2008.

LEONARDO, M.; BROETTO, F. BÔAS, R. L. V.; ALMEIDA, R. S.; MARCHESE, J. A. Produção de frutos de pimentão em diferentes condições salinas. Irriga, Botucatu, v.12, n.1, 2007.

NERY, A. R.; RODRIGUES, L. N.; FERNANDES, P. D.; CHAVES, L. H. G.; DANTAS NETO, J.; GHEYI, R. H. Crescimento do pinhão-manso irrigado com águas salinas em ambiente protegido. Revista Brasileira de Engenharia Agrícola e Ambiental, Campina Grande, v.13, p.551-558, 2009.

NEVES, M.F.; AMARAL, R. O. Flores - oportunidades e desafios- São Paulo: Revista Agro Analysis, São Paulo, v. 27, n. 9, p.30-31, 2007.

NOBRE, R. G.; ANDRADE, L. O.; SOARES, F. A. L. ; GHEYI, H. R.; FIGUEIREDO, G. R. G.; SILVA, L. A. da . Vigor do girassol (Helianthus annuus L.) sob diferentes qualidades de água. Revista Educação Agrícola Superior, Brasília, v. 23, n.1, p. 58-60, 2008.

PEREIRA, L. S.; PAREDES, P.; EHOLPANKULOV, E. D.; INCHENKOVA, O. P.; TEODORO, P. R.; HORST, M. G. Irrigation scheduling strategies for cotton to cope with water scarcity in the Fergana Valley, Central Asia. Agricultural Water Management, Amsterdam, v.96, n.5, p.723-735, 2009.

RACT, J.N.R.; GIOIELLI, L.A. Lipídios modificados obtidos a partir de gordura do leite, óleo de girassol e ésteres de fitosteróis para aplicação em spreads. Revista Química Nova, São Paulo, v. 31 n.8, p. 10 - 14, 2008.

RICHARDS, L. A. Diagnosis and improvement of saline and alkali soils, Washington: U.S, Department of Agriculture, 1954. 160 p. (HandBook, 60).

SANTOS JÚNIOR, J. A.; GHEYI, H. R; GUEDES FILHO, D. H.; DIAS, N. da S.; SOARES, F. A. L. Cultivo de girassol em sistema hidropônico sob diferentes níveis de salinidade. Revista Ciência Agronômica, Fortaleza, v. 42, n. 4, p. 842-849, 2011.

SCHNEITER, A.A.; MILLER, J.F. Description of sunflower growth stages. Crop Science, Madison, v.21, n.6, p.901-903, 1981.

SILVA, A. G. da; PIRES, R.; MORÃES, E. B. de; OLIVEIRA, A. C. B. de; CARVALHO, C. G. P. de. Desempenho de híbridos de girassol em espaçamentos reduzidos. Semina: Ciências Agrárias, Londrina, v. 30, n. 1, p. 31-38, 2009. 
SILVA, E. N.; SILVEIRA, J. A. G.; RODRIGUES, C. R. F.; LIMA, C. S.; VIÉGAS, R. A. Contribuição de solutos orgânicos e inorgânicos no ajustamento osmótico de pinhão-manso submetido à salinidade. Pesquisa Agropecuária Brasileira, Brasília, v. 44, n. 5, p.437-445, 2009.

SILVA, S. M. S.; ALVES, A. N.; GHEYI, H. R.; BELTRÃO, N. E. de M.; SEVERINO, L. S.; SOARES, F. A. L. Desenvolvimento e produção de duas cultivares de mamoneira sob estresse salino. Revista Brasileira de Engenharia Agrícola e Ambiental, Campina Grande, v.12, n.4, p.335342, 2008.

SOUSA, A. E. C.; GHEYI, H. R.; CORREIA, K. G.; SOARES, F. A. L.; NOBRE, R. G. Crescimento e consumo hídrico de pinhão manso sob estresse salino e doses de fósforo. Revista Ciência Agronômica, Fortaleza, v. 42, n. 2, p. 310-318, 2011.

SOUSA NETO, O.N.; DIAS, N.S.; FERREIRA NETO, M.; LIRA, R.B.; REBOUCAS, J.R. Utilização do rejeito da dessalinização da água na produção de mudas de espécies da caatinga. Revista Caatinga, Mossoró, v.24, p.123-129, 2011.

SOUZA, R.M. de; NOBRE, R.G.; GHEYI, H.R.; DIAS, N. da S.; SOARES, F.A.L. Utilização de água residuária e de adubação orgânica no cultivo do girassol. Revista Caatinga, Mossoró, v. 23, n. 2, p. 125-133, 2010.

TAIZ, L.; ZEIGER, E. Fisiologia vegetal. Porto Alegre: Artmed, 2004. p.449-484.

TRAVASSOS, K. D.; SOARES, F. A. L; GHEYI, H. R.; SILVA, D. R. S.; NASCIMENTO, A. K. S. do; DIAS, N. da S. Produção de aquênio de girassol irrigado com água salobra. Revista Brasileira de Engenharia Agrícola e Ambiental, Campina Grande, v. 15, n. 4, p. 371-376, 2011. 